\title{
PHYSICAL AND VERBAL VIOLENCE IN INDONESIAN FOLKTALES RETOLD IN CHILDREN'S BOOKS
}

\author{
Qanitah Masykuroh \\ Universitas Muhammadiyah Surakarta \\ qanitah.masykuroh@ums.ac.id
}

\begin{abstract}
Folktales as a cultural expression can contain all aspects of human life including violence. As Indonesia comprises so many diverse cultures, the context of violence, its degree and its nature, are also various. This study examines the forms of violence in Indonesian folktales, focusing on how physical and verbal violence are depicted in Indonesian folktales retold in children's books that were published in ten years of post-reformasi period. Content analysis is used to scrutinize the forms of violence. The finding shows that physical and verbal violence in Indonesian folktales retold as children's storybooks is prevalent. I argue that the diverse forms and nature of violence presented in children's story books illuminate the connection between social and individual expressions of violence. This study provides a way to look at the structural and ideological function of violence in contemporary traditional folk literature.
\end{abstract}

Keywords: physical violence, verbal violence, Indonesian folktales, children's books

\begin{abstract}
Abstrak
Cerita rakyat sebagai ekspresi budaya dimungkinkan untuk mengandung berbagai aspek kehidupan masyarakat termasuk kekerasan. Karena Indonesia meliputi aneka ragam budaya yang berbeda, konteks, tingkatan, serta sifat kekerasan yang ada dalam cerita rakyat juga beragam. Studi ini menanalisis bentuk-bentuk kekerasan dalam cerita rakyat Indonesia yang ditulis ulang dalam buku cerita anak yang diterbitkan dalam periode sepuluh tahun masa paska reformasi. Analisis isi digunakan sebagai alat untuk mengkaji bentuk-bentuk kekerasan tersebut. Hasil studi menunjukkan bahwa kekerasan fisik dan kekerasan verbal dalam cerita rakyat yang ditulis ulang dalam buku cerita anak cukup merata. Disamping itu, berbagai bentuk dan sifat kekerasan yang ada dalam buku cerita anak tersebut sedikit banyak menjelaskan hubungan anatara ekspresi kekerasan individu dan ekspresi kekerasan sosial. Hasil studi ini menjadi sebuah jalan untuk melihat fungsi struktural dan fungsi ideologis dari kekerasan dalam karya sastra tradisional kontemporer.
\end{abstract}

Kata kunci: kekerasan fisik, kekerasan verbal cerita rakyat Indonesia, buku cerita anak

\section{Introduction}

Folktales figure literary tradition in many cultures and are believed culturally significant and morally valuable. In addi- tion, folktales represent prototypes of later fictional developments. However, scholars who have research folktales as well as fairy tales have provided many examples which 
verify the presence of violence in folktales from various cultures and in all their various rewriting.

This can be seen for example in the mother's cruelty in the works of Grimm's Brother 'Grimm's Household Tales' (Haase 2008; Tatar 2004), the horror and violence in the Finnish folktales by Laura Soinne (Bengttson 2009), the child abuse in Setswana folktales, and the wife abuse in several Russian, Italian and British folktales (Ucko 1991).

Correspondingly, Indonesian folktales which are based on a great range of tribes' traditional oral literature and have been readapted in children storybooks show the prevailing image of violence. The prevalence of violence depiction is argued as closely related to some problems of folktales adaptation in the process of rewriting and publishing Indonesian folktales in children's books, one of which is the unawareness of the violent content in the folktales.

Children's books have long been one of the book genres in Indonesian book publishing industry. However, children's literature as a study and research interest has not been a concern of many Indonesian scholars until last two decades. The pioneer research related to children's literature in Indonesia is a study by Sarumpaet (1976) that investigates the characteristics and children's interest on storybooks. The later researches on children's literature are generally written as academic thesis. They generally concern with readers' response to children's books, the literary and linguistic aspects of children's literature texts and the use of children's literature in education. Additionally, there has been a growing interest to explore the gender aspect of children's literature as can be seen in (Soenarto \& Sutardjo 2000; Sarumpaet 2001; Wildan et al 2001; Cholifah 2003; Octavia 2006; Subiyantoro 2007).

Violence as a viable feature in children's literature has not attracted much attentiveness. There have been some previous studies on violence in children's literature but they mostly focus on violence in comics and magazine (Sunarto 2002; Sendjaja et. all 2003; Supriyadi 2009). Moreover, violence against women has been a majority of the type of violence investigated in the studies. The lack of attention on violence of print media for children is due to the supposition that violence in other media, especially audio visual media, is more harmful. Hence, much concern is given to audio visual violence than to children's books violence.

As what have been studied by some reputable western scholars, one of the genres in children's literature that is potential to enfold violence is folktales. Howev$\mathrm{er}$, in the case of the Indonesia, the folktales are commonly seen on merely their good cultural and moral values. As a result, the awareness of folktales violence to present in Indonesian children's literature is not immense. On the one hand, this unawareness together with inattentive rewriting and adapting the folktales has led to the prevalent image of violence in folktales for children. On the other hand, scholarly attention to the violence has not been great.

There are some scholars who have essentially initiated exploring the shadowy side of Indonesian folktales e,g. Soenarto \& Soetardjo (2000), Sarumpaet (2007), and Jatmika (2008). However, the violence scrutinized in these studies is typically on one kind of violence, violence against women. Other kinds of violence which include horror and sexuality have still been underdeveloped aspects of the study on folktales for children in Indonesia.

Whilst most people have no difficulty in recognizing an act of violence, it is notoriously problematic to define the term unambiguously. In part this is due to different intentions driving the creation of taxonomies, and so various methodologies and theoretical positions have been deployed.

Most definitions of violence focus on the inflicting of physical hurt and/or killing. The Australian Council on Children \& the Media (2009) defined violence as "a credible threat of physical force, or the application of physical force, intended to cause physical 
harm to an animate being or group of beings." They also emphasize that violence is defined by the intention to hurt. In the same way, Anderson and Bushman (2002, p.28) recognize violence as any behavior intending to cause harm, and/or has extreme harm as its goal (e.g. death). Further, Nancy Signorielly, from the US National Television Violence Study (2005), affirmed that the definition of violence also focuses on credible threats or the use of physical force and included all types of violence, and provided there was an intention to harm. A more elaborated definition is proposed by a media observer, Anu Mustonen (1997), who believes that psychological violence (aggressive humor, verbal abuse) should also be included. Her definition of violence includes physical or psychological actions (threats, non verbal behavior, and anger). The elaborative definition by Mustonen is used as a lens for understanding violence in the texts investigated.

\section{Research Method}

In this qualitative study, there are 115 Indonesian folktales books for children analyzed. The books are published in the period after Indonesian reformasi between 1998-2008, consisting of 111 individual storybooks and 4 compilation books. Content analysis is used to scrutinize the violent episodes in the stories. There are two forms of violence investigated in the texts: physical violence, and verbal violence. The violence in the texts discussed in this study is to some extent reflects the violence experienced in the daily life. Some forms of violence are cultural-specific which might be no longer in practice. Besides, the violence in folktales is not all of one kind and various types of violence are often interwoven in a violent episode. Moreover, violence is perpetuated by different motivation, is perpetrated by a variety of characters at different levels and settings, and is experienced in an array of ways.

Additionally, there are multiple ways to organize the violence in the texts. This study organizes the discussion of violence by type and severity, its setting, the perpetrators, by age and gender, motivation and by cultural context. Moreover, violence in folktales may be perpetrated individually, collective as in cultural sanction or disciplinary practice or structurally. As this chapter scrutiny the forms of violence, it focuses only on the type and severity of violence.

\section{Finding And Discussion}

\subsection{Physical violence}

Physical violence dominates the type of violence in the texts. This kind of violence falls under two categories: direct and indirect violence. Direct violence is indicated by the perpetrators' direct action of violence, by using parts of his body such as head, hand or foot, and/or by using weapons. Indirect violence is performed with the help of the third party. The third party can be human, animal or mystical creatures including God. In addition to the above categories, physical violence is also categorized based on the level of its severity: being hurt and being death.

\subsubsection{Direct violence}

The acts of violence ending up in hurting the victim are various, ranging from minor hurting until blood-spattered hurting. The violence embraces the various acts that parts of human body might do to perform violence such as punching, spitting, choking, slapping, twisting finger/arm, biting, cannibalism or sucking blood.

Correspondingly, the violence may end up in hurting or killing. The texts analyzed also reveal affluent acts of violence that utilize various kinds of weapon such as the acts of beheading, stabbing, slashing parts of body, committing mutilation, arrow shooting, poisoning, gun shooting, hanging, crusading, gauging eyes, burning alive, burying alive.

The complete types of direct physical violence can be seen in table 1 below: 
Table 1. Direct Physical violence based on the tools used

\begin{tabular}{|c|c|c|}
\hline & Violence acts using weapons as tools & Violence acts using parts of body as tools \\
\hline 1 & $\begin{array}{l}\text { swinging machete/sword on certain parts } \\
\text { of body: on neck, chest. Arms }\end{array}$ & kicking: head, body, arm, foot, face \\
\hline 2 & Beheading & hitting : head, body, back side of head, back \\
\hline 3 & knife and machete scratching, & punching: head, body, stomach, chest \\
\hline 4 & $\begin{array}{l}\text { stabbing (using knife, blade, sword, spear, } \\
\text { sharp-ended bamboo, arrow, calimprit) on } \\
\text { chest, stomach, arm, back, or foot }\end{array}$ & pinching: arms \\
\hline 5 & slashing parts of body: arm, ear, toe & pulling: arms \\
\hline 6 & $\begin{array}{l}\text { committing mutilation: mutilating body } \\
\text { into two parts or seven parts }\end{array}$ & forceful pushing \\
\hline 7 & tying someone to a tree or a pole, & spitting on face \\
\hline 8 & Trapping & Choking \\
\hline 9 & arrow shooting & slapping face \\
\hline 10 & Cannibalism & twisting: arm, finger \\
\hline 11 & killing using smoke & bumping head \\
\hline 12 & Poisoning & letting someone starving until die. \\
\hline 13 & gun shooting, & sucking blood \\
\hline 14 & hanging, & Dragging \\
\hline 15 & crusading, & $\begin{array}{l}\text { throwing kid into a hazardous place: into a } \\
\text { boiled water, into a crowd of crocodile. }\end{array}$ \\
\hline 16 & gauging eyes, & \\
\hline 17 & burning alive, & \\
\hline 18 & burying alive, & \\
\hline 19 & $\begin{array}{l}\text { heap piling someone in a deep hole until } \\
\text { die: with stone or with lime stone, }\end{array}$ & \\
\hline 20 & drowning someone until die, & \\
\hline 21 & clogging someone's mouth with dirt & \\
\hline 22 & $\begin{array}{l}\text { suppressing someone using big stone, } \\
\text { wood }\end{array}$ & \\
\hline 23 & Whipping & \\
\hline 24 & throwing magical seed & \\
\hline
\end{tabular}

It is interesting to note that some of the weapons used in violent acts denote the traditional specific weapons in Indonesia such as Sumpit (a traditional blowgun from Kalimantan), Keris (a traditional knife from Java with zigzag shape and sharp end), Celurit (a traditional weapon from Madura shaping like a big crescent knife), Straut (a traditional weapon from Sumatra shaping like a knife with a curved end), Calimprit
(A traditional weapon from Bali shaping like a long chain with a metal ball at the end), Mandau (a traditional weapon from Dayak shaping like a big long knife), Kelapan (a traditional weapon from Riau shaping like an arrow).

In addition to the acts of violence and the weapons and tools used, the depiction of violent acts also various from the common acts of fighting until the bloody hurting and 
killing. These acts can be seen in the following examples:

a. In the story of 'Jaka Budug', the violent is shown when Jaka Budug, a boy with scabies who suffered banishment because of his physical condition, fought with a snake in his journey to find the cure for his skin disease. The act of violence was in the form of killing intensified by the presence of blood.

\section{"After a long fighting, Joko Budug finally killed the snake. Afterwards, he took the snake's blood and used it to wash his body and amazing- $l y$, all the scabies on his body van- ished. " (Book 1)}

b. In the story of 'Arya Penangsang', a story of royal conflict between Arya penangsang and Jaka Tingkir with the setting of the kingdom of Demak. After the death Sultan Trenggana, the king of the Demak kingdom, the throne was passed to Jaka Tingkir, his son in law. Arya Penangsang who was the senior contender thought he deserved more for the throne and challenged Jaka Tingkir. The violence was shown in the form of horrible depiction of post violent act of stabbing.

"Arya Jipang pulled his keris, not realizing that he was stabbed and his intestine draped on the keris. As a result, his intestine was pulled off and shattered. He screamed out of pain, fell down off his horse and died." (Book 110)

c. In the story of Nyi Mas Kanti, the story of sibling rivalry with the theme of kind and unkind girl, the violent act was in the form of cutting off the protagonist heroine's arm by the female villain. The bloody and horrible depiction after the act intensified the violence depiction.

"Having thrown with a sword, the right arm of Nyi Mas Kanti was cut off and fell down on the grass and the spatter of the blood make the green grass turn into red." (Book 115)

Similarly, in the different event of the same story in which Nyi Mas Kanti was finally healed, got her arm back and married to a price, there was a violent act performed by Nyi Mas Kanti's husband who fought a rage bull attacking the capital city.

"The bull was stabbed on his eyes, and blood was so spurted on his face that he could not see the way he ran. He ended crashing a wall and died with a badly damaged face being crushed by the broken wall." (Book.115)

d. In the story of Danawa Sari, a story about women rivalry, the violent act was performed by the female villain Danawa sari who wanted to be the king's wife. She gauged the queen's eyes to ruined her beauty and put her in an isolation.

“Danawa Sari gauged the queen's eyes and threw them to a river, leaving the queen in an agonizing cry." (Book 86)

e. When the queen was finally saved, another violent act was shown when the prince did the revenge by torturing Danawa Sari.

"The Prince dragged the wounded Danawa Sari to the underground jail and the queen put salt on her wound, making her feel unbearable sore." (Book 86)

f. In the story of 'Kebo Iwa' a buffalo-headed man who won a competition to win a princess, the violent act was in the form of torturing. This torture was done by soldiers ordered by the princess who denied to have a beast husband.

"All the soldiers threw lime stone into the hole where Kebo Iwa was inside, and they heap piled the hole 
with the stones, not caring to his cry for help." (Book 100)

\subsubsection{Indirect Violence}

The finding of the analysis shows that the indirect violent acts are not less malicious than the direct violence. Although the violent acts are not directly depicted, the order and instruction might lead to the horrible imagination of the implying violent acts.

The indirect violence aiming at hurting is in the forms of hurting bodies, typically by requesting someone to do act of poisoning. The indirect violence aiming at killing is typically the instruction to kill in which some of the instructions are added with the requirement to provide a proof of death in the form of head or ear.

\section{"The Patih was ordered to kill the} princess and to bring her head and her blood as the proof of her murder." (Book 105) the cut ear:

In another story variant, the proof is

"The soldiers were instructed to kill the man and to bring his ear as the proof of his death. "(Excerpt 5, Book 160)

A detail execution of violence is obviously illustrated in the story of Putri Pucuk Geleumpang, a story about an effort of a father to vanish his daughter. In this story violence is explored quite prevalently.

The story starts some weeks before the born of the baby. Some weeks before, the husband went to another town. He told his wife to kill the baby if his wife gave birth to a baby girl as his maids that he would be embarrassed to have a daughter and the daughter would not give him any advantage provoked him.

"If you gave birth to a baby boy, I would make him a cockfight successor, but if you gave birth to a baby girl, slaughter her, cook the meat and fed it to my rooster." (Excerp 7; Book 160)
Unfortunately, the wife gave birth to a baby girl. The wife tried to protect her daughter by slaughtering a goat instead of her daughter, and she hid her daughter in the forest. When her husband went home the wife told him that she had did what he told her. However, the husband's rooster, that can talk, told the husband that the wife lied. The husband was very angry and asked the wife to bring home their daughter to be killed. After several times the wife went back and forth to the forest unsuccessfully asked her daughter to go home, then the impatience husband went to the forest holding bringing swords and some arrows. He asked her daughter who stayed in a high cabby house up in the tree to walk down on a ladder made of swords. When the daughter walked down the ladder, the father shot one arrow and the arrow hit her hair. She asked her mom what that was and her mom answered that it was a hair clip, a present given by her father to her. Subsequently, on every step of the ladder she walked down, the daughter got an arrow from her father and the arrows hit her neck, her chest and he stomach, her waist, and her foot, and similar to the first arrow, the daughter's questioned her mom and were answered that the arrows were necklace, brooch, belt and foot bracelet. After getting down and meeting her father, the daughter gave him a fabric she weaved, and then she asked him to find a proper place to kill her. Then they go to the middle of the forest. When the father swung the sword, suddenly a banana tree turned out replacing her position. The daughter herself was hiding behind trees. Realizing that her daughter had disappeared, the father regretted himself. Afterward, he went to find his provocative maids and killed them using his sword. Finally, the daughter lived happily with her mom.

\subsubsection{The events implying the acts of physical violence}

Another way to portray physical violence in the texts is by implication. Stories usually describe an event depicting the re- 
sult or the condition of post physical violence. The post violence condition generally include the level of severity which sometimes too bloody and horrible. The following excerpts confirm the implication.

"Ni Jerum found her mother died in the old unused well; she was found without head. Somebody must brutally kill her." (Book 165)

The portrayal of the dead body without head implied that someone or something has done a violent action resulting in the separation of the head from its body.

"They found Ratu Agung was dead, and his hands were nailed on

\section{a tree." (Book 35)}

In the excerpt above, the fact that Ratu Agung was dead and was posited in a horrible condition imply that someone has killed him and crusade him on the tree. In relation to the implying of violent acts, the transitivity analysis of the texts indicates that certain process types are generally used in implying violent acts and might be used for some purpose of representation.

Additionally, there are three types of the portrayal of post violence conditions i.e. the portrayal of states involving the presence of blood, the portrayal of horrible condition of the body damage, and the portrayal of the severe condition of hurt.

Table 2. Types of post violence portrayal

\begin{tabular}{|c|c|c|}
\hline & $\begin{array}{c}\text { Types of post violence } \\
\text { portrayal }\end{array}$ & Examples \\
\hline 1 & $\begin{array}{l}\text { States involving the } \\
\text { presence of blood }\end{array}$ & $\begin{array}{l}\text { The blood was dropping off her cut off arm. } \\
\text { He screamed in agony while covering his face that severely } \\
\text { whipped. } \\
\text { The blood was spurting out of his body, the blood sparred all over } \\
\text { the cave. } \\
\text { His body was stained with blood. } \\
\text { Anywhere in the field, soldiers were bloody dead. } \\
\text { He toppled down and his stomach was bloodily ripped off. } \\
\text { The green grass soon turned out to be red with blood. The water in } \\
\text { the river was turning red because of the blood of the two fighting } \\
\text { animals. } \\
\text { He fell down and black blood came out of his mouth, indicating } \\
\text { that he got serious internal injured. } \\
\text { The giant ate up Putri, leaving nothing but a drop of blood under } \\
\text { the ladder. }\end{array}$ \\
\hline 2 & $\begin{array}{l}\text { Horrible description of } \\
\text { body damage }\end{array}$ & $\begin{array}{l}\text { Died with the slashed off neck, died with the almost separated head } \\
\text { from his body, Died with severely damaged body. Died with body } \\
\text { shattered into pieces. Died with broken head. Died with seriously } \\
\text { burned body. Loreng was dead with his head off. The corpse rot- } \\
\text { ting and some parts the body missing. }\end{array}$ \\
\hline 3 & $\begin{array}{l}\text { The severe condition of } \\
\text { hurt }\end{array}$ & $\begin{array}{l}\text { Being sprawling badly on the sand, being slammed and sound of } \\
\text { the cracked bones was herd, being seriously burnt, being thrown } \\
\text { away and broken his leg, being dropping off with head first, falling } \\
\text { down on the ground and unable to walk anymore, Being hurt on the } \\
\text { chest feeling like getting stabbed }\end{array}$ \\
\hline
\end{tabular}

Having described the acts of physical violence, it is clear now that the physical violence in Indonesian folktales for children depicts great diverse kinds of physical violence some of which seems cruel and excessive. Although some kinds of violence might never be really done or no longer practiced by society, the presence of that violence in traditional literature provides indication that those violent ideas have ever come across the life of the society. 


\subsection{Verbal violence}

In folktales, verbal violence is a type of violence that does not usually stand alone in the sense that verbal violence is a result of other kind of violence or even a trigger for a violence act. In the texts analyzed, the verbal violence can be classified into twelve acts: labeling, thread to kill, thread to hurt, humiliation, thread to hurt beloved people, swearing, mother's denial, scolded anger, curse and telling mother's origin to her child.

Table 3. Verbal Violence

\begin{tabular}{|c|c|c|}
\hline & Types of verbal violence & Examples \\
\hline 1 & Labeling & $\begin{array}{l}\text { stupid, lazy, crazy, coward, ugly, slummy, malodorous, ungrate- } \\
\text { ful, ill-mannered, shameful, Jahanam (one of the Hell's names, } \\
\text { usually used to describe the evil character), son of a bitch }\end{array}$ \\
\hline 2 & Thread to kill & $\begin{array}{l}\text { "I'll kill you", “....or I'll take your life." } \\
\text { "Surrender or perish." } \\
\text { "Surrender or we separate your head from your body." "I will } \\
\text { chomp you." } \\
\text { "Be ready to go to hell." } \\
\text { "If you do not do that, you will be slaughtered instead." } \\
\text { "Tell me the secret or I'll kill you" }\end{array}$ \\
\hline 3 & Thread to hurt & $\begin{array}{l}\text { "Get my revenge." } \\
\text { "Get the consequence" }\end{array}$ \\
\hline 4 & Humiliation & $\begin{array}{l}\text { "Is this ugly woman your mother?" } \\
\text { "I am sick of your face." } \\
\text { "Banish this insane woman." }\end{array}$ \\
\hline 5 & $\begin{array}{l}\text { Thread to hurt the be- } \\
\text { loved people }\end{array}$ & $\begin{array}{l}\text { "If you give birth to a son, he will replace me as a cockfighter, } \\
\text { but if you give birth to a girl she will be slaughtered and given } \\
\text { to my rooster." }\end{array}$ \\
\hline 6 & Swearing & "Damn you", "Shit" \\
\hline 8 & Denial & $\begin{array}{l}\text { "You are not my mother." } \\
\text { "My mother is not poor and dirty like you." } \\
\text { "I don't have such a dirty mother like you, don't you ever say } \\
\text { that you are my mother". }\end{array}$ \\
\hline 9 & Scolding anger, nagging & $\begin{array}{l}\text { He was terribly angry to see the empty plate, The father in law's } \\
\text { maids kept telling her about her debt. The wife was so angry }\end{array}$ \\
\hline 11 & Curse & $\begin{array}{l}\text { "If it is true that he is my son, Oh my Lord I beg your justice." } \\
\text { "You are stubborn like a stone." } \\
\text { "Oh Lord give him a cognition." } \\
\text { "You will hang in trees like monkeys." } \\
\text { "Oh Lord transform him into a stone." } \\
\text { "Oh Lord give him a lesson." } \\
\text { "Oh Lord give him a warning." } \\
\text { "I curse the girls in this village that they would become single } \\
\text { unmarried women ever or they would not get married before } \\
\text { they reach the age of forty". }\end{array}$ \\
\hline 12 & $\begin{array}{l}\text { Telling mother origins to } \\
\text { her child }\end{array}$ & $\begin{array}{l}\text { "Son of a fish." "Son of a stick." } \\
\text { "You are naughty kid, son of an Undan bird", "You are son of } \\
\text { a flying thing", }\end{array}$ \\
\hline
\end{tabular}

Among the twelve kinds of verbal violence, mother's denial, curse and telling mother's origin to her child are of the typi- cal verbal violence existing across Indonesia cultures.

Mother's denial and curse are inter- 
woven verbal violence in curse folktales. Citraningtyas (2004) found at least 10 curse Indonesian folktales with Malin Kundang theme. This kind of folktales are ended with the son or the daughter transformed to nonalive thing such as stone, tree, or bird as well as vanished by a disaster.

It is important to note that the analysis also finds a tendency to change the source of curse in folktales for children. In some stories, curse is no longer portrayed as mother's curse, but God's curse. Mother's role is to commit the prayer to God, and it is God who decides the kind of punishment. This new adaptation made by the children's book publisher might reflect the repositioning of a mother as a good figure. However, at the same time the repositioning reduces the holy position of mother as the representation of God.

Another typical verbal violence is telling a mother's origin to her child. Six folktales from different cultural origins are found to portray this kind of verbal violence. In such folktales, mother's origin is believed to be the key power of a woman to engage with human man and at the same time the man's promise not to tell the woman's origin to her kids is a kind of covenant marriage. This is due the status of the woman who originally comes from non-human world such as from bird, fish, stick, or fairies. Hence, telling a mother's origin to her kid becomes a form of divorce declaration. In the texts analyzed, all the six folktales are ended with unexpected separation because of the husband's carelessness. Accordingly, telling mother's origin to her child turns into verbal violence.

\section{Conclusion}

Indonesian folktales have long been preserved and encouraged to be instilled to children as a means of character education, considering the positive and beneficial moral values they encompass. Meanwhile, folktales as the reflection of human culture are a potentially valuable site for the representation of all human traits involving violence. The finding of this study confirms the existence of violence in Indonesian folktales. Despite the problem of adaptation and rewriting process of the folktales that has led to the unawareness of violent content in folktales retold for children, the depiction of rich variety of violent acts might indicate the various forms of violence that might be found in the society.

\section{References}

Anderson, C.A.. \& Bushman, BJ. (2002). Human Aggression. Annual Reviews of Psychology, no. 53, pp.27-51.

Australian Council on Children and media Violence (2009). Overview of the effects of violence in the media. Retrieved from http://www.youngmedia.org.au/mediachildren/ overview_violence.html

Bengtsson, N. (2009). Sex and Violence in Fairy Tales for Children. Bookbird: A Journal of International Children's Literature, vol. 47, no.3, and pp.15-21.

Cholifah (2003). Anafora dan Katafora pada Wacana Dongeng Anak serta Implikasinya bagi Pembelajaran Bahasa dan Sastra. (Unpublished Thesis). Jakarta State University.

Citraningtyas, C.E. (2004). Old Tale for New People : Indonesian Curse Folktales retold for Children. Seriously Playful: Genre, Performance and Text, Sharyn Pearce and Kerry Malan (eds). Queensland: Post Pressed Australia

Djatmika (2008). Dongenge Kancil karo Asu Belang: Keprihatinan Verbal dan Moral Pen- 
gajaran Sastra Jawa di SD Kelas 1. A paper presented at HISKI $19^{\text {th }}$ International Literature Conference.

Haase, D. (2004). Fairy Tales and Feminism. Detroit: Wayne State University Press.

Mustonen, A. and Pulkkinen, L. (1997). Television Violence: Development of a Coding Scheme. Journal of Broadcasting and Electronic Media, no. 41, pp.168-189.

Octavia, W. (2006). Tokoh Dewasa Gigi Kelinci dan Ketika Potter Hilang dlam Pandangan Anak.. (Unpublished Bachelor Thesis). University of Indonesia

Sarumpaet, R.K. (1976). Bacaan Anak-Anak . Jakarta: Penerbit Pustaka Jaya.

----- (2001). Tokoh dalam Bacaan Anak Indonesia. Makara Jurnal Penelitian Universitas Indonesia Vol 5, No. 2 pp. 24-29

----- (2007). Batu Permata Milik Ayahanda: Dongeng Traditional Indonesia. Jurnal Perempuan No 54 pp. 74-85

----- (2010). Pedoman Penelitian Sastra Anak. Jakarta: Yayasan Obor Jakarta.

Sendjaja, Djuarsa,S., Menayang,V., Sunarto, Maryani,E., Widyawati, N., \& Bharata,B.S. (2003). Reaktualiasasi Cerita Anak-Anak : Eliminasi Kekerasan Terhadap Perempuan Dalam Media Anak-Anak Indonesia. (Unpublished Research Report). University of Indonesia.

Signorelli, N. (2005). Violence in the Media. California: ABC-CLIO,

Subyantoro (2007). Model bercerita untuk Meningkatkan Kepekaan Emosi dalam Berapresiasi Sastra : Korelasi Model Bercerita Berdasarkan Analisis Tokoh Cerita Anak-anak. (Unpublished Doctoral Thesis). Jakarta State University

Sunarto, R.T. (2000). Analisa Discourse Ideologi gender media Anak-Anak. (An unpublished Research Report). Diponegoro University, Semarang Indonesia

Supriyadi, J. (2009). Analisis Ijime dalam Komik Life karya Keiko Suenobu. (Unpublished Bachelor Thesis). North Sumatra University of Indonesia.

Tatar, M. (2004). The Hard Facts of the Grimms' Fairy Tales. New.Jersey: Princeton University Press.

Ucko, L. G. (1991). Who's Afraid of the Big Bad Wolf? Confronting Wife Abuse through Folk Stories. Social Work Vol. 36 No. 5, pp. 414-19

Wildan, Faridah, A., Yusuf,H., Saadiyah (2001). Dongeng Anak-Anak dalam Bahasa Aceh: Analisis Struktur. Jakarta: Pusat Pembinaan dan Pengembangan Bahasa Depdiknas. 